\title{
Management of acid sulfate soils under aerobic and anaerobic soil conditions revolves around organic matter and live plant macrophytes
}

\author{
Patrick Michael $^{1 *}$
}

\begin{abstract}
Submitted: 14 June 2019 | Accepted: 10 January 2020

In acid sulfate soils (ASS), it is well established that sulfuric soil acidity is managed by application of a neutralising agent and sulfidic soil oxidation is prevented by water table management. This review summarizes recent studies using organic matter in amelioration of sulfuric soil acidity and curtailing of sulfidic soil oxidation by discussing the changes induced on soil $\mathrm{pH}$, Eh and sulfate contents under varying soil moisture regimes. Increase in low pH, low Eh values and reduction in sulfate content have been observed in sulfuric and sulfidic soil following organic matter amendment under aerobic and anaerobic soil conditions. When organic matter co-existed with live plants, $\mathrm{pH}$ decreased with correspondingly high Eh values and high sulfate contents in almost all cases, even under anaerobic soil conditions. Practical consideration shows that application of organic matter by incorporation and spot application as surface mulch followed by establishment of plants under general soil use and management conditions create microniches conducive for root growth and negate the mechanisms that lead to severe acidification associated with live plants.
\end{abstract}

Keywords: Acid sulfate soils, organic matter, live plants, $\mathrm{pH}$, redox potential, sulfate content

\section{INTRODUCTION}

In managed soils, application of a neutralising agent such as an agricultural lime is the most common practical method to manage soil acidity. In these soils, the quantity of the neutralising agent required is often met because of the smaller size of the farmland. In ASS, the quantity of lime needed is economically unfeasible and practically impossible to apply (Charoenchamratcheep et al 1987) due to the wider

'Department of Agriculture, PNG University of Technology, Lae, MP 411, Papua New Guinea

\footnotetext{
*Corresponding Author. Address: Department of Agriculture, PNG University of Technology, Lae, MP 411, Papua New Guinea; Email: patrick.michael@pnguot.ac.pg DOI: $10.32945 /$ atr4211.2020
} 
global occurrence (Figure 1). In some economies, eg. Papua New Guinea (PNG), having access to refined agricultural lime is expensive (Michael et al 2016). In addition, application of lime to treat acidity in protected areas, eg. Ramsar-listed wetlands is prohibited (Michael et al 2017). The goal of this review is to summarize the findings of recent studies of the effects of organic matter addition and live plants on soil pH, redox potential and sulfate content of ASS with the aim of establishing alternative strategies to manage the negative impacts. Studies investigating the ameliorative effects of organic matter addition are gaining momentum and this review provides an important background for continuity.

\section{APPROACH OF REVIEW}

The findings of recent studies conducted in the last five years related to organic matter addition and establishment of live plants on ASS $\mathrm{pH}$, redox and sulfate content available in the ASS literature were reviewed in the following manner. Firstly, the formation processes of sulfidic and sulfuric soils are discussed. Secondly, in doing so the adverse impacts on the environment are pointed out. Thirdly, the need for developing alternative management strategies compared to use of lime is established. Fourthly, high quality studies using organic matter and live plants and their importance as alternative management strategies are discussed. Finally, a synthesis of the major studies is done, and based on that the need for future studies is highlighted.

\section{FORMATION AND OCCURRENCE}

\section{Acid Sulfate Soils}

Acid sulfate soils are naturally occurring soils, sediments or substrates formed under waterlogged, reducing conditions (Pons 1973). The global occurrence of ASS is shown in Figure 1. These soils either contain sulfuric acid $\left(\mathrm{H}_{2} \mathrm{SO}_{4}\right)$ or have the potential to form it, in an amount that can have adverse impacts on the environment (soil properties, water \& living things) (Dent 1986, Dent \& Pons 1995). In an undisturbed state below the water table, sulfidic soils are benign, unless exposed due to natural processes or anthropogenic activities (Fitzpatrick et al 2008).

\section{Sulfidic Soils}

Joukainen and Yli-Halla (2003) reported that ASS have formed within the last 10,000 years after the last sea level rose (Michael 2013). When the sea level rose and inundated the land, sulfate in sea water mixed with iron oxides and decomposable organic matter in the sediments, allowing sulfate reducing bacteria (SRB) to form iron sulfide minerals ( $\mathrm{FeS}_{2}$; pyrite) under anaerobic soil conditions (Canfield et al 2006). This process is shown in equation (Equation 1).

$$
\mathrm{Fe}_{2} \mathrm{O}_{3(\mathrm{~s})}+4 \mathrm{SO}_{2(\mathrm{aq})}+8 \mathrm{CH}_{2} \mathrm{O}+1 / 2 \mathrm{O}_{2(\mathrm{~g})} \rightarrow 2 \mathrm{FeS}_{2(\mathrm{~s})}+8 \mathrm{CHO}_{3 \text { (aq) }}+4 \mathrm{H}_{2} \mathrm{O}_{(\text {aq) }} \quad \text { Equation } 1
$$


Management of acid sulfate soils under aerobic and anaerobic soil conditions

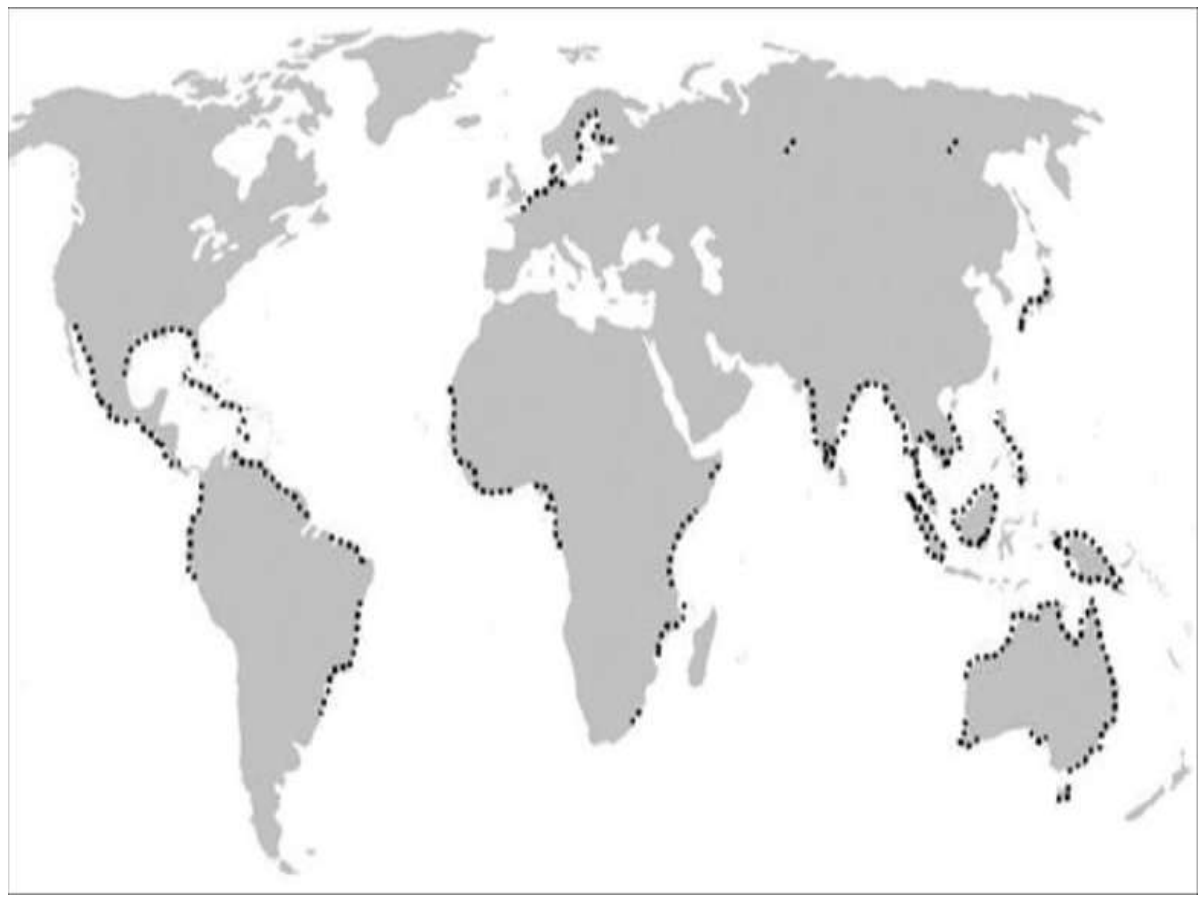

Figure 1. On estimation, 17-24 million ha of the global soil is ASS of which 6.5 million occur in Asia, 4.5 million in Africa, 3 million in Australia, 3 million in Latin America, 260000 in Finland; 225000 in Sweden and 100000 in North America, respectively (Simpson \& Pedini 1985, Ljung et al 2009).

\section{Sulfuric Soils}

Under the natural water table, sulfidic poses no problem unless the $\mathrm{FeS}_{2}$ (Equation 1) is exposed and reacts with atmospheric oxygen and form $\mathrm{H}_{2} \mathrm{SO}_{4}$ (Fitzpatrick et al 2010, Nordmyr et al 2008, Ward et al 2004a). This process is shown in Equation 2. Release of the $\mathrm{H}_{2} \mathrm{SO}_{4}$ in turn dissolves the soil matrix in which iron species $\left(\mathrm{Fe}^{2+}, \mathrm{Fe}^{3+}\right)$, aluminium $\left(\mathrm{Al}^{3+}\right)$ and other toxic soil constituents (elements, metals or metalloids) are held, releasing them into the soil-water systems (Ljung et al 2010, Ljung et al 2009, Nordmyr et al 2008, Roos \& Astrom 2005). Generation and propagation of $\mathrm{H}_{2} \mathrm{SO}_{4}$, mobilisation and transportation of constituents are the main processes through which ASS poses adverse ecological impacts (Michael 2013). A typical polluted farm drain with iron flocs with sulfuric soil material is shown in Figure 2. There are several chemical processes which result in the oxidation and generation of the $\mathrm{H}_{2} \mathrm{SO}_{4}$ as reviewed by Michael (2013). The overall oxidation process that generates acidity in the absence of acid neutralising capacity of the soil (Cook et al 2000, Lin et al 2000) is shown by Equation 2.

$$
\mathrm{FeS}_{2(\mathrm{~s})}+3^{3 / 4} \mathrm{O}_{(\mathrm{g}, \mathrm{ag})}^{2}+3 \frac{1}{2} \mathrm{H}_{2} \mathrm{O} \rightarrow \mathrm{Fe}(\mathrm{OH})_{3}+2 \mathrm{SO}_{4}^{2-}+4 \mathrm{H}_{(\text {aq) }}^{+} \quad \text { Equation 2 }
$$




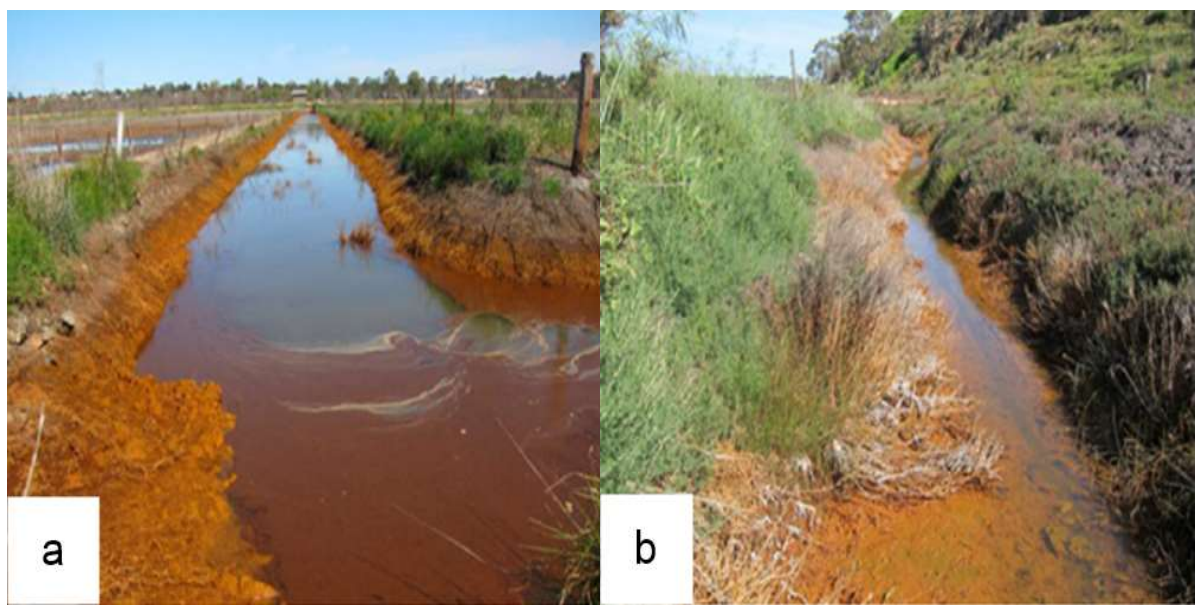

Figure 2. Polluted farmland drains near (a) Murray Bridge and (b) Toora, South Australia with iron flocs containing dominantly Schwertmannite which is formed because of the presence of ASS with sulfuric materials adjacent to the drains (Fitzpatrick et al 2012)

\section{Current Management of Acid Sulfate Soils}

The impacts are widespread and of global significance; however, under different environmental conditions the impacts are different and need tailored management strategies (Thomas 2010). A good number of studies showed the importance of the impacts on various components of the environment (Powell \& Ahern 1999, Powell \& Waite 2000, Vegas-Vilarrubia et al 2008) and strategies have been developed based on two key principles (Bloomfield \& Coulter 1973, Dent 1992). The first principle is to minimise disturbance and to prevent and slow the extent of pyrite oxidation (Ward et al 2004b). The second principle is to neutralise the actual sulfuric acidity by application of a neutralising agent, such as an agricultural lime (Dear et al 2002, Fitzpatrick et al 2010). Mitigation, rehabilitation, retaining existing acidity and discharge management received considerable attention (Cook \& Gardner 2001, Cook et al 2000).

\section{Effects of Organic Matter Amendments}

In almost all other natural and managed soil types, organic matter is mainly found in the top $20-30 \mathrm{~cm}$ of the soil, often known as the rhizosphere. Those that are available as detritus, root exudates or synthesized by microbes are initially of plant origin. The importance of organic matter to soil functions, the soil biophysical and biochemical processes that take place, the micro- and macroflora and fauna that dwell in the soil are well documented (eg, Howarth 2007, Wardle 2002, Coleman \& Wall 2007, Hopkins \& Gregorich 2005, Billings \& Ziegler 2005). In ASS, organic matter is the energy source for sulfate reducers to initially form sulfidic soil materials (Equation 1) and an attractive remedial agent in sulfuric soil material (Dear et al 2002, Fitzpatrick et al 2009, Baldwin \& Fraser 2009). Unlike in other soil types, availability of organic matter in ASS is low because of limited turnover of plant matter from a few acid tolerant plants and reduced microbial activities 
Management of acid sulfate soils under aerobic and anaerobic soil conditions

because of severe acidity. Limitation of organic matter in ASS is further compounded by the limited biological activity, binding to clay particles or complexion by metals that have dissolved as a result of dissociation reaction at the extremely low $\mathrm{pH}(<4)$. Consequently, the most economical use and application of organic matter in ASS under field conditions warrant further research with good progress made in recent studies (eg, Michael et al 2015).

As pointed out earlier, sulfidic soils pose no problem unless disturbed or the water table that maintains anoxia has fallen, eg, due to anthropogenic activity such as drainage or natural processes such as a drought event, resulting in oxidation. What happens to the soil chemistry when plant matter or similar substrates are added under the undisturbed condition or when exposed is quite not established. Michael et al (2012) reported from a study lasting 2 weeks conducted under laboratory conditions that addition of alkaline sandy loam $\left(\mathrm{pH}_{\mathrm{w}}\right.$ 9.4) buffered the residual effects of sulfuric soil $(\mathrm{pH}<4)$ when mixed and the $\mathrm{pH}$ rose to circumneutral level $(\mathrm{pH}>6)$. When the same substrate was mixed into sulfidic soil and maintained at $75 \%$ water-holding capacity (henceforth aerobic soil condition), oxidation was prevented, making the $\mathrm{pH}$ to remain above 6.5 units (Michael et al 2012). When this short-term study was repeated with the treatments incubated for 6 months, mixing of the alkaline sandy loam soil in sulfuric soil increased the $\mathrm{pH}$, lowered the oxidation reduction potential (redox) and reduced the sulfate content, the magnitude of the changes dependent on the soil moisture content (Michael, 2015a). The results on $\mathrm{pH}$ and redox were even better when lucerne hay with $3.2 \%$ nitrogen was added as organic matter together with the alkaline sandy loam. The changes induced were quite effective under aerobic than flooded soil conditions. The variability seems to come from oxidation of organic matter being more efficient with sufficient oxygen and less efficient under anoxia. The mechanisms responsible for creating a microenvironment conducive to consume acidity (proton), reduce sulfate content and increase the $\mathrm{pH}$ when organic matter is added as per Koschorreck (2008) is shown in Equation 3. This chemical reaction shows organic matter is the limiting factor in sulfidic soil oxidation and amelioration of sulfuric soil, that is increase the $\mathrm{pH}(\mathrm{pH}>4)$.

$$
2 \mathrm{CH}_{2} \mathrm{O}+\mathrm{SO}_{4}^{2-}+2 \mathrm{H} \rightarrow \mathrm{H}_{2} \mathrm{~S}+2 \mathrm{CO}_{2}^{2-}+2 \mathrm{H}_{2} \mathrm{O} \quad \text { Equation } 3
$$

In managed agro-ecosystem, organic matter is placed in the soil using two common approaches: (i) applied as mulch on the surface and (ii) incorporated. These are shown in Figure 3. Under natural conditions, surface organic matter comes from senesced plant matter (eg, leaf litter) and in the deep soils exudation of organic compounds from the roots. Under agricultural soil use and management conditions, the first approach is practised to suppress weeds, retain soil moisture or improve the structure of the surface, eg, establishment of plants. Therefore, the actual placement of the organic matter is on the surface $(0-5 \mathrm{~mm})$. The second approach is undertaken to provide the soil with nutrients, and application is within the top $20-30 \mathrm{~cm}$ of the rhizosphere. Some form of tillage is required to incorporate the organic matter. Most commonly, this is achieved by initially laying the organic matter on the surface and ploughing into the soil. The same is achieved by 
growing legumes or cover crops as green manure. Unlike in the first approach, the second approach adds organic matter evenly throughout the rhizosphere (20$30 \mathrm{~cm}$ ), making the soil conditions conducive for root growth. In ASS, studies considering these approaches are limited to a few recent studies, such as Michael et al (2015a) and Yuan et al $(2015 a, b)$.

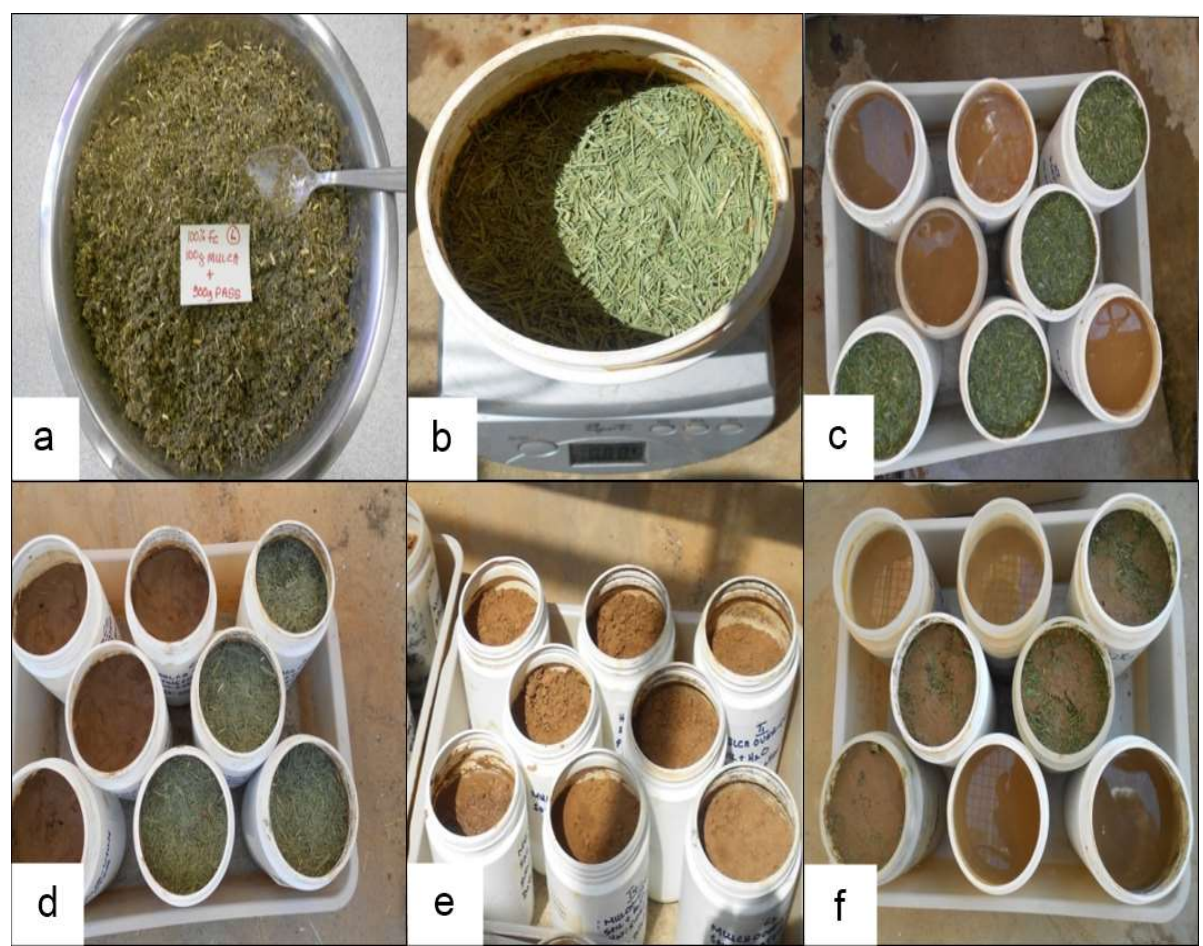

Figure 3. Application of organic matter in small pots $(140 \mathrm{~cm}$ tall): (a) incorporation by bulk mixing, (b) overlaying as surface mulch, (c) overlaying under flooded conditions, (d) overlaying under aerobic, (e) incorporated under aerobic and (f) under anaerobic conditions, respectively (Michael 2015b)

The work of Michael et al (2012) was further extended by mixing alkaline sandy loam soil with sulfuric soil $(\mathrm{pH}<3)$. The $\mathrm{pH}$ of the mixture $(1: 3 \mathrm{w} / \mathrm{w}) \mathrm{was}_{\mathrm{p}} 6.7$ and $\mathrm{pH}_{\text {ox }} 2.8\left(\mathrm{pH}_{\mathrm{w}}\right.$ is measured in soil: water solution $\& \mathrm{pH}_{\mathrm{ox}}$ is measurement after peroxide treatment), with a field capacity of $28 \%$. Dry leaves of $P$. australis $(3.7 \% \mathrm{~N})$ were either overlaid on the surface and maintained under anaerobic soil conditions or incorporated and maintained under aerobic soil condition, respectively. Applications of organic matter in all the treatments were made at 80:1 (soil: organic matter $\mathrm{w} / \mathrm{w}$ ). Under aerobic conditions, organic matter addition sustained the near neutral $\mathrm{pH}$ obtained by mixing (Table 1), compared to the unamended mix soil that strongly acidified to near 4 units (Michael et al 2015). Under anaerobic soil conditions, the opposite happened. The $\mathrm{pH}$ of the amended and unamended soil both dropped but the changes were within the range of $5-6$ units, with the changes in 
Management of acid sulfate soils under aerobic and anaerobic soil conditions

the unamended soil near 5 and amended near 6 units (Michael et al 2015), respectively. Redox of the unamended soil was near $400 \mathrm{mV}$ but the amended soil was below $-200 \mathrm{mV}$. Sulfate reduction was consistent with the changes in $\mathrm{pH}$ and redox in both treatments. The changes in $\mathrm{pH}$, redox and sulfate content measured were dictated by the organic matter content of the alkaline sandy loam as supported by the organic matter amendment. The most interesting question that needed answers was the major components of the amendments that induced the changes. Although the nitrogen content of the organic matter was known, other resources in the form of carbon needed by soil microbes were only estimated against those of Rynketal (1992).

Table 1. Effects of organic amendments either on sulfidic or sulfuric soil $\mathrm{pH}$, Eh and sulfate content

\begin{tabular}{|c|c|c|c|c|c|c|c|}
\hline $\begin{array}{c}\text { Amendment } \\
\text { types }\end{array}$ & $\begin{array}{l}\text { Application } \\
\text { methods and } \\
\text { amounts }\end{array}$ & $\begin{array}{l}\text { ASS } \\
\text { types }\end{array}$ & $\begin{array}{l}\text { Moisture } \\
\text { conditions }\end{array}$ & $\mathrm{pH}$ & $\begin{array}{l}\text { Eh } \\
(\mathrm{mV})\end{array}$ & $\begin{array}{l}\text { Sulfate } \\
(\mu \mathrm{mol} \\
\left.\mathrm{g}^{-1}\right)\end{array}$ & References \\
\hline $\begin{array}{l}\text { Phragmites } \\
\text { leaf }\end{array}$ & $\begin{array}{l}\text { Incorporated } \\
(80: 1)\end{array}$ & Sulfuric & Anaerobic & 7.8 & -50 & 4.0 & $\begin{array}{l}\text { Michael et al } \\
(2015)\end{array}$ \\
\hline $\begin{array}{l}\text { Phragmites } \\
\text { leaf }\end{array}$ & $\begin{array}{l}\text { Incorporated } \\
(80: 1)\end{array}$ & Sulfuric & Aerobic & 7.6 & 150 & 3.0 & $\begin{array}{l}\text { Michael et al } \\
\text { (2015) }\end{array}$ \\
\hline $\begin{array}{l}\text { Phragmites } \\
\text { leaf }\end{array}$ & Overlaid (80:1) & Sulfuric & Anaerobic & 7.1 & 650 & 8.0 & $\begin{array}{l}\text { Michael et al } \\
\text { (2015) }\end{array}$ \\
\hline $\begin{array}{l}\text { Phragmites } \\
\text { leaf }\end{array}$ & Overlaid (80:1) & Sulfuric & Aerobic & 5.0 & 500 & 24.0 & $\begin{array}{l}\text { Michael et al } \\
\text { (2015) }\end{array}$ \\
\hline Leucerne hay & $\begin{array}{l}\text { Incoporated } \\
(80: 1)\end{array}$ & Sulfuric & Aerobic & 8.0 & -200 & 4.0 & $\begin{array}{l}\text { Michael et al } \\
\text { (2016) }\end{array}$ \\
\hline Pea straw & $\begin{array}{l}\text { Incoporated } \\
(80: 1)\end{array}$ & Sulfuric & Aerobic & 6.0 & -100 & 5.0 & $\begin{array}{l}\text { Michael et al } \\
(2016)\end{array}$ \\
\hline Wheat straw & $\begin{array}{l}\text { Incoporated } \\
(80: 1)\end{array}$ & Sulfuric & Aerobic & 5.9 & -80 & 9.0 & $\begin{array}{l}\text { Michael et al } \\
(2016)\end{array}$ \\
\hline Leucerne hay & $\begin{array}{l}\text { Incoporated } \\
(80: 1)\end{array}$ & Sulfidic & Aerobic & 7.9 & 100 & 1.0 & $\begin{array}{l}\text { Michael et al } \\
(2016)\end{array}$ \\
\hline Pea straw & $\begin{array}{l}\text { Incoporated } \\
(80: 1)\end{array}$ & Sulfidic & Aerobic & 7.8 & 180 & 2.0 & $\begin{array}{l}\text { Michael et al } \\
\text { (2016) }\end{array}$ \\
\hline Wheat straw & $\begin{array}{l}\text { Incoporated } \\
(80: 1)\end{array}$ & Sulfidic & Aerobic & 5.5 & 300 & 5.0 & $\begin{array}{l}\text { Michael et al } \\
(2016)\end{array}$ \\
\hline
\end{tabular}


Michael et al (2016) attempted to answer the question above by amending sulfuric and sulfidic soils with organic matter of varying nitrogen content (Phragmites leaf $3.7 \%$, lucerne hay $3.2 \%$, pea straw $1.2 \%$ \& wheat straw $0.8 \%$ ) and laboratory grade simple nitrogen and carbon compounds (Table 1). Glucose, sodium acetate, and molasses were used as carbon and sodium nitrate sources; ammonium chloride and urea, as nitrogen sources, respectively (Table 2 ). In the sulfuric soil, organic matter addition increased the $\mathrm{pH}$, dependent on the nitrogen content (Table 1). The mechanism for these changes to be that shown by Equation 3 . Lucerne hay highly increased the $\mathrm{pH}$ and reduced the redox and the sulfate content. The least was measured from the wheat straw, dependent on its nitrogen contents. Organic matter addition had similar effects on $\mathrm{pH}$, redox and sulfate content of the sulfidic soil under the aerobic conditions (Table 1). The changes being similar in both soils indicated that the same mechanism (shown by Equation 3 ) was operating. None of the carbon compounds were as effective as the organic matter or the effects were variable (Table 2). Possible reasons for this variability in the changes induced were pointed out by Koschorreck (2008).

When the simple nitrogen compounds were added alone, nitrate or ammonia had no effect on $\mathrm{pH}$ and the sulfate content (Table 2). The probable reason is that reduction of nitrate to nitrite inhibited the functions of dissimilatory sulfite reductase (Haveman et al 2004, Kaster et al 2007). Addition of urea as organic nitrogen also containing carbon raised the $\mathrm{pH}$ to 6.3 units, reduced the soil to $0 \mathrm{mV}$ and had no effect on the sulfate content (Tables $2 \& 3$ ). These indicated that organic matter addition has the capacity to neutralise sulfuric soil acidity and prevent sulfidic soil oxidation even under exposed soil conditions, the main driver for inducing the changes measured being nitrogen. The exact time over which the beneficial effects occur, how long the organic matter lasts and when new additions need to be made and how much can be needed for general soil use and management were not clear in the studies shown in Tables 1-3. Addition of lucerne hay in sulfuric soil under anaerobic conditions increased the $\mathrm{pH}$ by 5.5 units in three days from an initial $\mathrm{pH}$ of 4.4 and sudden decrease in the redox, compared to the slow changes in the unamended soil (Michael 2017). This showed that organic matter is an important substrate to induce immediate changes in soil chemistry as shown in other studies (eg, Michael et al 2015, Jayalath et al 2016). On field-scale, organic matter application (estimated for acre-furrow-slice weighing 1000 tonnes) was estimated to be between 29.8 (80:1, soil: organic matter) and 149 (80:5) tonnes per ha (Michael et al 2016). We have demonstrated that the alkalinity generated by organic matter addition is sufficient to last for 6 months (Michael et al 2016). The sole reason being depletion of resources from the decomposition of organic matter, preventing microbes to continue to function. 
Management of acid sulfate soils under aerobic and anaerobic soil conditions

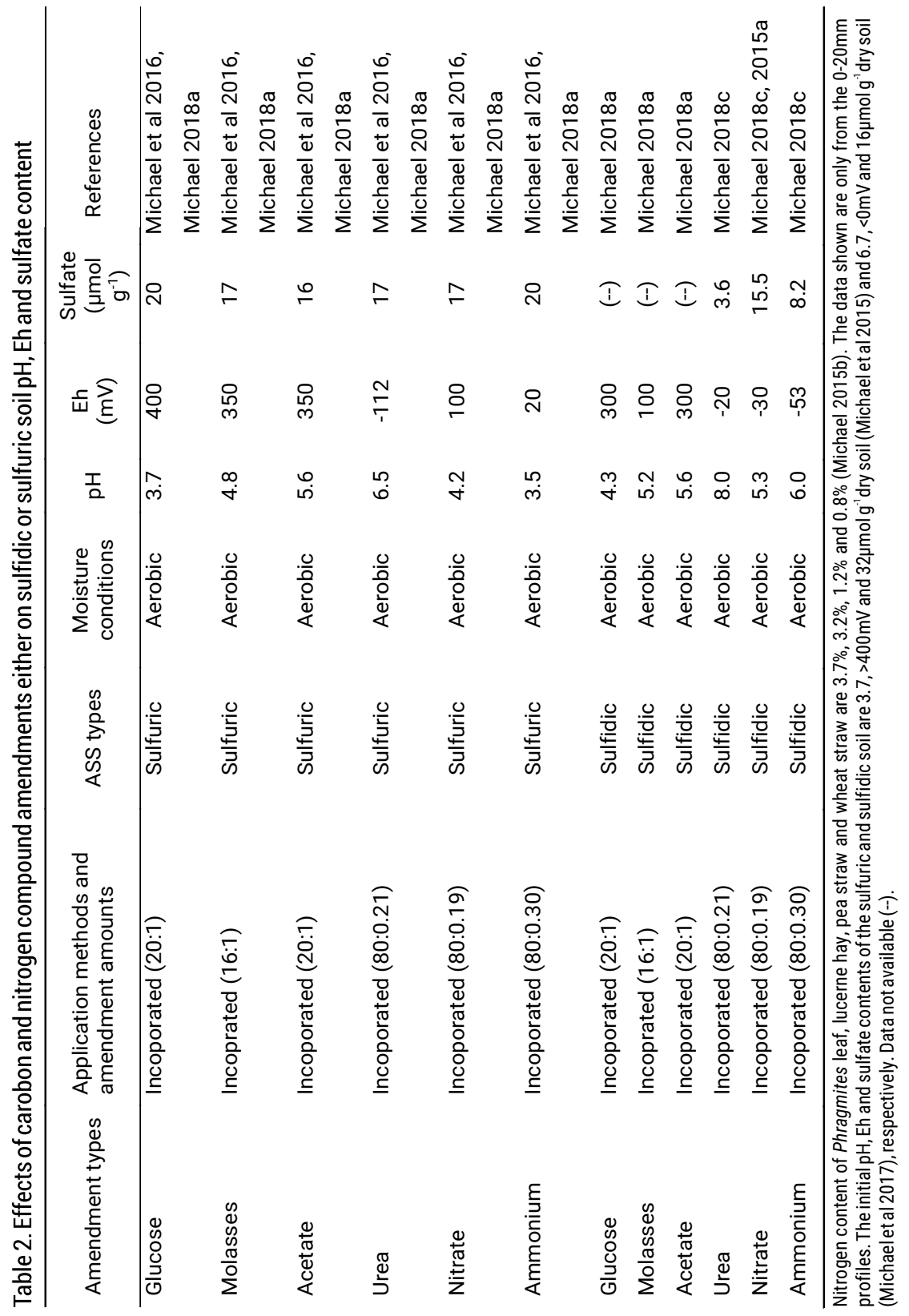


Michael

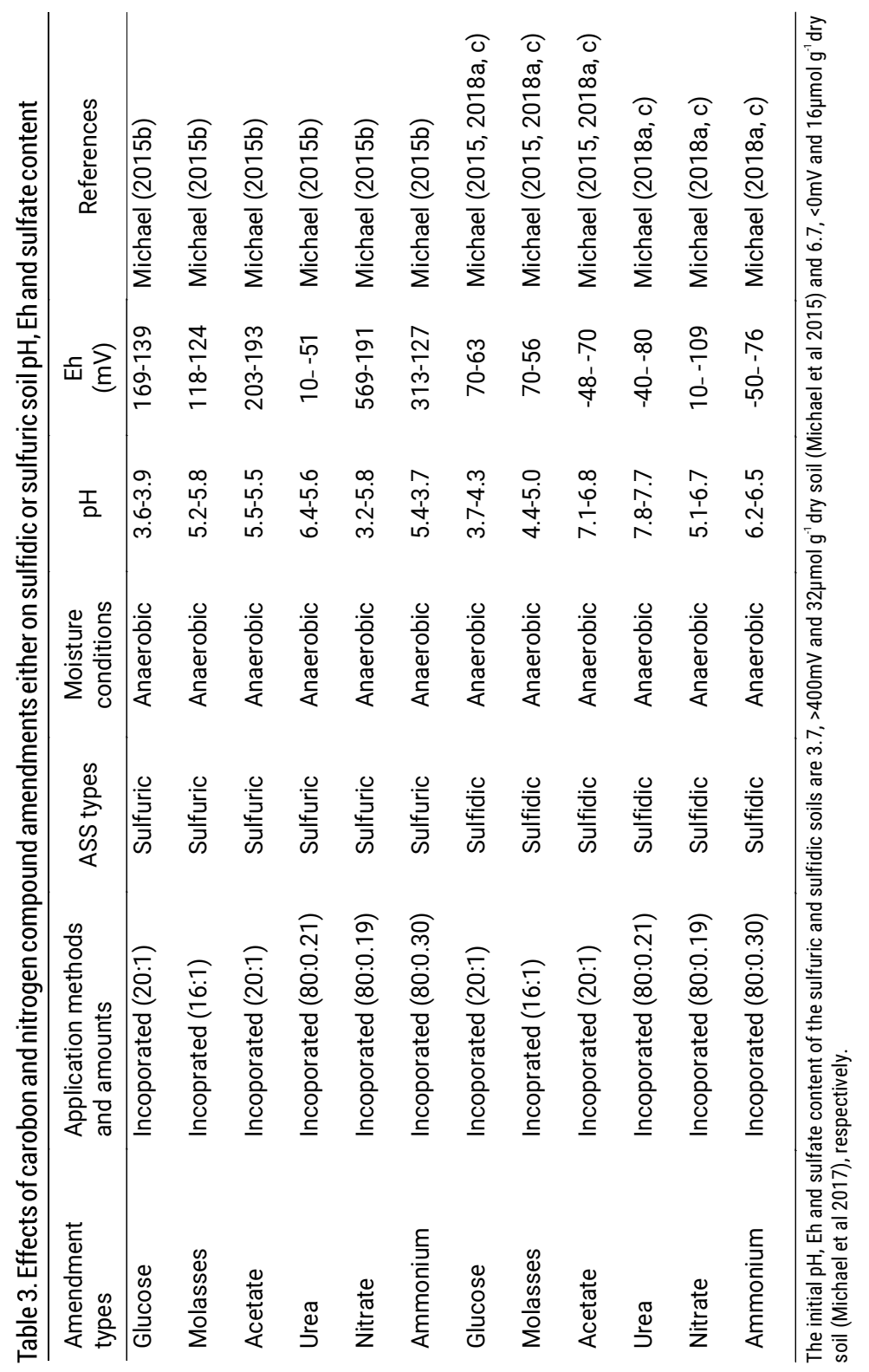


Management of acid sulfate soils under aerobic and anaerobic soil conditions

\section{Effects of live plants alone or co-existing with organic matter}

In planted soils, turnover of organic matter and secretion of organic substances influence microbial activity and alter the soil chemistry (Marks et al 1994, Dubey \& Sahu 2014, Fanning 2015). Several studies have shown addition of organic matter ameliorates sulfuric soil and stabilises the $\mathrm{pH}$ of sulfidic soils (eg, Michael et al 2015, Jayalath et al 2016). On the other hand, Reid and Butcher (2011) reported live plants acidify sulfidic soil and lower the $\mathrm{pH}$. Under natural soil use and management conditions, plant turnover adds decaying organic matter so that both live and dead plant materials co-exist (Yan et al 1996). This interesting phenomenon of live plants co-existing with dead plant material and the influence on main soil chemical parameters that characterise ASS ( $\mathrm{pH}$, Eh \& sulfate content) are not widely investigated until recently.

To assess the effects of live plants alone, a number of common wetland and inland plants were chosen and planted under aerobic and anaerobic soil conditions over a period of 12 months. Melaleuca ericifolia, Typha domingensis and Phragmites were planted in sulfuric and sulfidic soils (Table 4). Compared to the changes in the unplanted aerobic soil, Melaleuca and Typha led to acidification, highly oxidised soils and had minimal effect on the sulfate content (Table 4). The effects on the soil properties were similar when the same plants were established in sulfidic soil under the same moisture conditions. Phragmites plants established in both soils under the moisture conditions gave rise to similar results. When compared, the results were clearer, the high $\mathrm{pH}(>6)$ decreased to near 5 units, redox values were above $0 \mathrm{mV}$ and sulfate content was reduced by nearly $60 \%$, compared to a $25 \%$ decrease in the control soil (Table 4). The mechanism underlying the adverse effects of live plants can be related to the processes occurring when the live plants and the dead plant material is either incorporated (Connell \& Patrick 1968) or distributed as surface mulch (Michael et al 2012, 2015, 2016, 2017) and coexist.

The combined effects of live plants and organic matter co-existing was studied by Michael and Reid (2018) by establishing Phragmites plants in sulfuric soil either under aerobic or anaerobic soil conditions. The same plant species was established in sulfidic soil and maintained under aerobic conditions to compare the results. Chopped Phragmites leaves were used as organic matter and incorporated by bulk mixing (Table 4). In all the studies, the planted soils acidified, more so in the aerobic soil with only the surface soil pH raised to near 6 units and deeper soils mainly remaining acidic, consistent with Shamshuddin et al (2004) and Tinh et al (2001). In the anaerobic soil, the control soil pH rose to 6 units throughout the profiles as expected compared to the drop in the planted soil pH to near 5 (Michael \& Reid 2018). Redox was highly oxidised in the aerobic soil than in the anaerobic soil and the changes in the sulfate content corresponded with these changes. In the planted sulfidic soil, pH lowered to 6 units, compared to the 5.5 units measured in the sulfuric soil under the same soil moisture conditions (Table 4). 
Michael

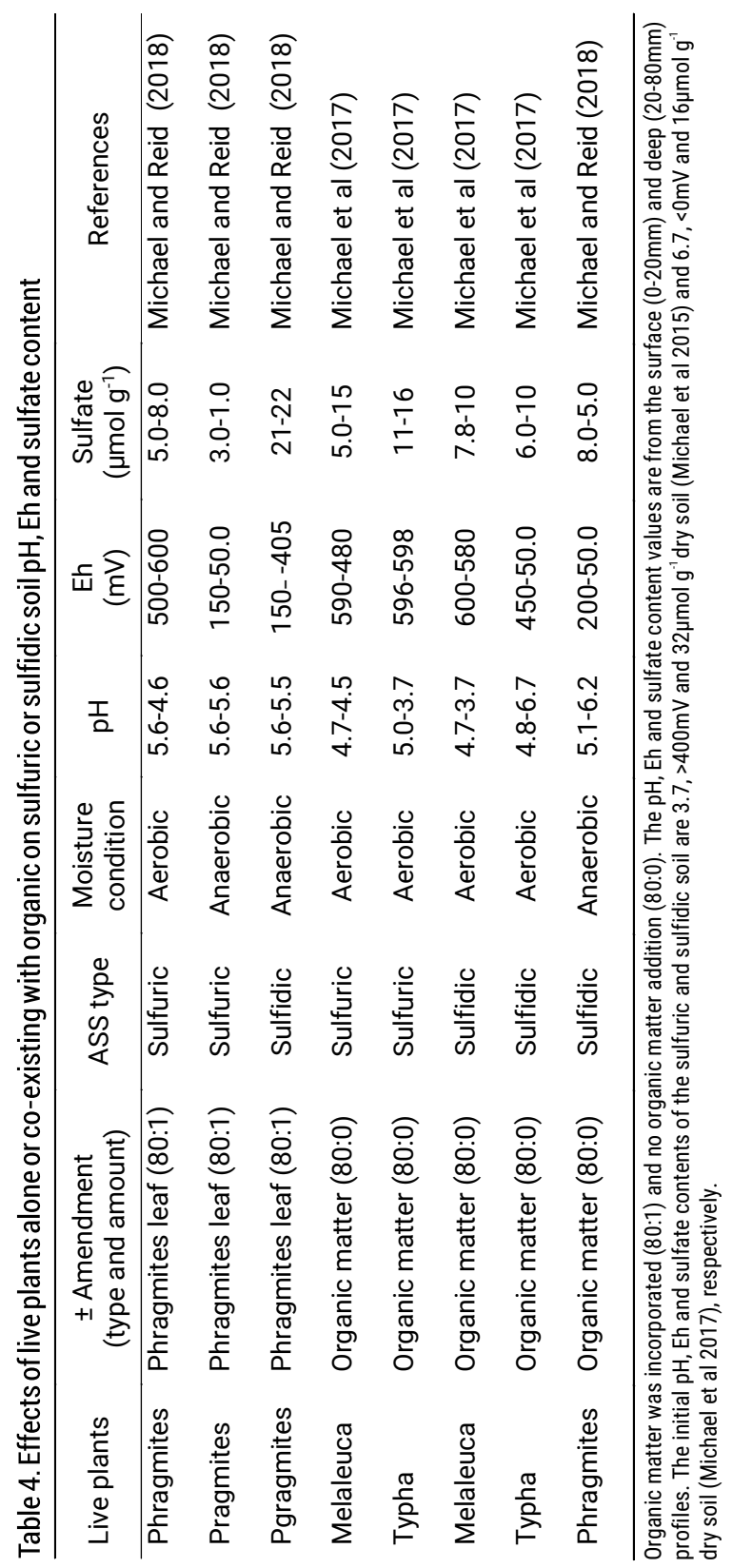


Management of acid sulfate soils under aerobic and anaerobic soil conditions

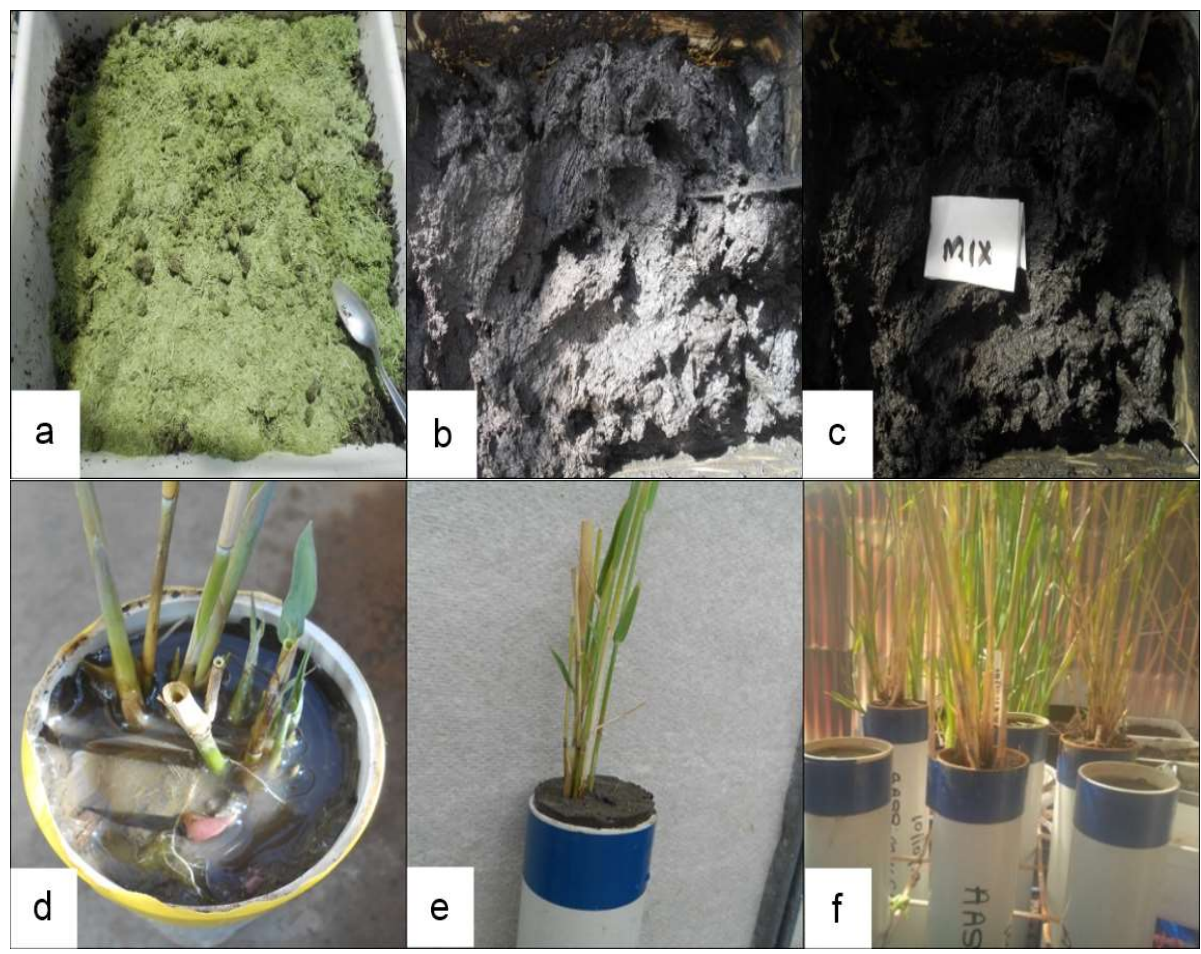

Figure 4. Sample photos showing (a) bulk mixing of organic matter, (b) sulfuric soil with organic matter mix, (c) mix sulfidic soil, (d) rooted shoots of Phragmites transplanted in $45 \mathrm{~cm}$ tall stormwater tube, (e) young shoots germinating and (f) mature Phragmites prior to harvest (Michael 2015b)

\section{Management Strategies}

There are ranges of management options available for treating ASS, such as those in Melville and White (2012), but none of these involve organic matter and live plants. This review aimed to put together practical strategies for treating ASS using dead or live plants. An associated aim was to try to understand how lives plants impact the chemistry of the soils when co-existing with organic matter, other than just the $\mathrm{pH}$, including microbial activity that produces or consumes acidity. Drawing on the review, it is possible to make some informed commentary on the suitability of plants for treating ASS in different scenarios.

\section{Sulfidic Soil Exposure}

In the event that the surface of a sulfidic soil dries rapidly, there may be less of a tendency to acidify as there is need for water in the oxidation process (Equation 2). This was demonstrated in the experiments in which soils were wetted to different extents (studies shown in Tables 1-3). Clearly the best strategy for treatment of exposed sulfidic soil is reflooding, which on its own prevents acidification. However, this is often not possible, especially in prolonged drought, so alternative strategies need to be employed. Incorporation of organic matter such as 
Phragmites leaves, lucerne hay or pea straw is very effective in stabilising or even increasing the soil pH (eg, Michael et al 2016). This scenario is likely to arise along river beds and in wetlands where Phragmites commonly grows abundantly (Michael \& Reid 2018).

Prolonged droughts often result in death of plants and these plant matters end up mostly on the soil surface and some in deep profiles from roots. These organic matters would offset, to certain extent the acidity generated by the drought events and oxidation. The rapid loss of soil moisture would in turn hinder oxidation process, and even reduce mobility of acidic minerals, toxic metals and metalloids (Ward et al 2004a, Cook et al 2001, Rigby et al 2006). The main requirement for mulching material appears to be high nitrogen content. For this reason, plant material such as wheat straw, which has a low nitrogen content, is much less effective (eg, Michael et al 2015). If mechanical incorporation is not practical because of the unstable nature of the soil, an alternative treatment recognised is the application of urea, which can be applied directly to the surface as a solution.

Revegetating-exposed sulfidic soils does not appear to be advisable since in most of the studies in which plants were established, the $\mathrm{pH}$ decreased, in some cases to quite a large extent; in the other studies the $\mathrm{pH}$ did not change relative to the unplanted control soil, but there were no instances in which the $\mathrm{pH}$ was increased by live plants (Michael \& Reid 2018). Acidification by live plants is always associated with increases in Eh, suggesting that plants increase penetration of oxygen (Armstrong 1980) thereby increasing oxidation of soil sulfides. Slashing the shoots back to the ground level reduces oxygen transport but the culms continue to be the conduit (Michael et al 2017, Michael \& Reid 2018).

\section{Treatment of ASS}

The treatments mentioned are applicable to soils targeted for agricultural use. Where water is available, keeping the soils under a layer of water would maintain neutral $\mathrm{pH}$ and be suitable for wet crops, eg, rice (Oryza sativa) and taro (Colocasia eculenta). For dryland agriculture though, the incorporation of plant mulches would have the beneficial effect of increasing and stabilising the $\mathrm{pH}$ but at the same time would lower the Eh due to the oxygen demand created by microbial breakdown of organic matter. Under both anaerobic and aerobic conditions, urea was shown to cause large increases in $\mathrm{pH}$. If used as the nitrogen fertiliser, this could have beneficial effects on both plant growth and soil $\mathrm{pH}$.

Reflooding of exposed sulfuric soil allows a gradual reversal of the oxidation process, but this can be greatly accelerated either by incorporation of organic matter, such as Phragmites leaf, or simply applying it to the surface as mulch. Under non-flooded conditions, applying organic matter to the surface was shown to increase $\mathrm{pH}$ by 1 to 1.5 units but when incorporated the $\mathrm{pH}$ increased by up to 4 units (Table 3). Even though application just to the surface was not as effective as incorporation, the results from the flooded treatment suggests that surface organic matter on exposed sulfuric soil would cause the $\mathrm{pH}$ to increase much faster upon submerging. As for sulfidic soil, vegetating sulfuric soil can enhance acidification and therefore is not recommended. The treatment options for sulfidic soil carry the same advantages and drawbacks when applied to sulfuric soil. Organic mulches, especially those high in nitrogen, as well as urea, all cause substantial reductions in Eh that may inhibit root growth into the soil under crop production. 
Management of acid sulfate soils under aerobic and anaerobic soil conditions

\section{Plant Organic Matter vs Agricultural Lime}

It is clear that application of organic matter has beneficial effect in stabilising or increasing the $\mathrm{pH}$, in both sulfuric and sulfidic soils. This is beneficial not only when applied to the soil surface but also when incorporated at depth. Under some circumstances, stabilisation may be sufficient. For example, application of surface mulch to sulfuric soil under low moisture conditions resulted in a moderate increase in pH (Michael et al 2015). Perhaps this is due to the lack of surface moisture for microbial activity, which in itself would inhibit oxidation. However, without excess water, mobilisation of acidity and toxic elements is less likely. The problem arises with heavy rain or reflooding, which can transport acids and toxins away from the site. As noted above, surface organic matter can, when flooded, lead to large increases in $\mathrm{pH}$, which would inhibit such transport. The question is, how does this compare to lime?

Economically, plant organic matter may be much less expensive, especially in areas with low labour costs for harvesting and distributing the plant material. Lime, unless highly purified and therefore more expensive, can contain contaminant materials and is not permitted for treatment of environmentally important wetlands. One example is the Ramsar-listed wetlands of Lake Alexandrina and Lake Albert in the lower Murray-Darling Basin of South Australia, which underwent severe acidification during Australia's Millennium Drought, and lasted for 5 years. However, it was deemed necessary to apply agricultural lime even though it was not allowed. Part of the problem was that there appeared to be no alternatives because little was known about the effectiveness of applying plant organic matter, especially in the over 20,000ha of the dried-out and cracked sulfuric soil, which was previously submerged lake beds and wetlands (Fitzpatrick et al 2009). Liming may be impracticable and costly in such large areas, in high clay content or problems related to dissociation reactions. As noted previously, generation of alkalinity by microbial degradation of plant matter causes changes in redox conditions that may be detrimental to plant growth, and therefore less appropriate for crop production except under flooded conditions. A compromise may be to apply amounts of organic matter that maintain a moderate Eh and lessen the amount of lime that needs to be used, especially in agriculture. In places where revegetation is required but difficult conventionally, spot application of organic matter is an important approach (Michael et al 2017, Michael \& Reid 2018).

\section{The Mechanisms of the Effects of Organic Matter and Live Plants}

Most literatures on ASS mainly consider $\mathrm{pH}$ changes in terms of oxidation or reduction of sulfur compounds, and to a lesser extent, oxidation and reduction of iron and nitrate. Decaying plant matter contributes carbon, nitrogen and other nutrients that can act as both energy suppliers and electron acceptors for a range of microbes (Yuan et al 2015a, b). This microbial activity influences the oxygen status of the soil and changes the redox conditions to suit different groups of the microbial ecology (Fortin et al 1996). In our studies (eg, Michael et al 2015, 2016, 2017), breakdown of complex organic matter that led to increases in $\mathrm{pH}$ was associated with loss of sulfate from the soil and reduction in Eh. This suggested that the principal, but not necessarily only, process that contributed alkalinity is sulfate 
reduction, both in the sulfidic soil undergoing oxidation and sulfuric soil which has already undergone oxidation and produced acidity, assuming no labile organic matter, or soil material capable of neutralising acidity is present. In addition, organic matter decomposition consumes oxygen, forms complexation with ferric iron and may even coat pyrite (Bush et al 2004, Ward et al 2004b). We observed overlaying of organic matter on the surface of sulfidic and sulfuric soils reducing the redox conditions sufficient to prevent oxidation and generate alkalinity (Michael et al 2015, 2016, Michael 2018a, b).

Addition of carbon alone (eg, glucose) did not result in significant changes in soil sulfate content and the $\mathrm{pH}$ changes caused by the carbon compounds maybe due to microbes other than (Michael et al 2016). Simple carbohydrates, acetate and glucose have quite different effects most likely because of different metabolic pathways (Koschorreck 2008). Acetate caused pH to increase and Eh to decrease, whereas glucose lowered the $\mathrm{pH}$ whilst Eh remained high (Michael et al 2016). Molasses increased the $\mathrm{pH}$ to near 5 and Eh was high to come from the diversity in microbial ecology present to generate alkalinity utilizing the resources. SRB strains Desulfovibrio and Desulfosporosinus utilize hydrogen as an energy source but not acetate (Widdel 1988). Complex carbon sources like glucose inhibit sulfate reduction, when simple organic substrates have the opposite effects (Koschorreck 2008).

To this end, the requirement for nitrogen was not clearly established. Simple nitrogen compounds in the form of nitrate or ammonia do not seem to induce either large increases or decreases in $\mathrm{pH}$ or Eh, which may indicate that the main limitation is carbon. When nitrogen was applied in combination with carbon in the form of urea or molasses, $\mathrm{pH}$ increased and redox decreased, but there was little evidence of sulfate reduction that accompanied these changes (Michael et al 2015). However, the strong correlation between nitrogen content of plant materials and the effectiveness in ameliorating both sulfidic and sulfuric soils suggested that microbial breakdown of complex organic molecules requires nitrogen as a nutrient source (Michael 2018a). One study reported high nitrate concentration inhibited sulfate reduction, but the inhibitory effect was removed by high organic matter addition (Yuan et al 2015b).

The general observation by quite a number of studies was that live plants acidify soil, most likely by increasing oxygen penetration (Armstrong 1980, Tornberg et al 1994, Reid \& Butcher 2011, Michael \& Reid 2018). The possible mechanisms for this are oxygen transport in aerenchyma tissues in the root and loosening of soil as plant roots grow (Michael et al 2017). These mechanisms operate to compensate for the water losses on the surface of the leaves and used up in the tissues of live plants. When soils are flooded, pore spaces are taken up by water and oxygen penetration into the soil is limited. As such, oxidation and resultant acidification ensured from the oxygen pumped into the soil by plants capable of delivering oxygen using their modified tissues, especially under anaerobic conditions. In drylands, roots crack up the soil and facilitate oxygen to penetrate, resulting in oxidation and acidification. Some acid may be generated by microbial activity metabolising compounds excreted by roots (sugars, organic acids \& amino acids). Under revegetation conditions, plants such as Phragmites are able to strive because their roots are able to grow through the sulfuric horizon $(\mathrm{pH}<4)$ quickly into the sulfidic horizon $(\mathrm{pH}>4)$ as an adaptive mechanism to avoid 
Management of acid sulfate soils under aerobic and anaerobic soil conditions

acidity and concentrate biomass, above or below ground the sulfuric horizon (Michael \& Reid 2018, Michael et al 2017, Fanning 2015). Turnover of these biomasses following senescence and death would result in more organic matter addition either on the surface from litter or incorporated in the deep profiles from the roots, offsetting the negative impacts.

\section{Future Research}

One of the main limitations of the studies reviewed is that the effects of treatments on soil chemistry are only a snapshot at one point in time. The few time course experiments showed that soil responses can vary quite markedly depending on when measurements were made (Michael 2017). Some treatments may cause changes quite rapidly while others more gradually and maybe sustained for longer period. One study showed a large effect of organic matter in sulfuric soil after 6 months, but after 12 months the conditions were similar to the untreated control (Michael et al 2017). In relation to the point mentioned, the results of studies we reported (eg, Michael et al 2015, 2016, 2017) were all obtained under laboratory and glasshouse conditions and need to be validated under field conditions and using a wide variety of ASS. Most of findings presented are from studies conducted under glasshouse conditions. The added organic matter were chopped up to suit the experimental conditions and on a field-scale, the quantity of organic matter applied (estimated for acre-furrow-slice weighing 1000 tonnes) was between 29.8 (80:1, soil: organic matter) to 33.5 (90:1) tonnes per ha (Michael et al 2016). Therefore, the practicality of adding coarse plant materials and their beneficial effects on soil chemistry in real-time situations, such as in farms or Ramsar-listed wetland soils, need to be tested. Another significant gap relates to the limited insight obtained regarding the mechanisms of the changes in $\mathrm{pH}$, in particular the microbial systems are mainly responsible. Sullivan et al (2010) reported positive relationship between organic carbon and sulfate reduction in a lake sediment containing sulfuric soil which seems to be accompanied by rise in $\mathrm{pH}$. Polynucleotide analysis of SRB from sulfuric soil amended with organic matter and incubated for a month revealed Desulfovibrio, the common SRB acting on the organic matter and reducing sulfate content (Michael 2018a). These important mechanisms need to be thoroughly investigated.

\section{CONCLUSIONS}

It appears that nitrogen compared to carbon is the most limiting factor in generation of alkalinity by soil microbes. Nitrogen may be needed by sulfate reducers for growth when carbon meets the energy demands. Under general soil use and management conditions, addition of organic matter alone in aerobic than in anaerobic soil is effective in increasing the $\mathrm{pH}$, reducing the redox and sulfate reduction, important for crop agriculture. In some instances, organic matter is applied in soils to serve various purposes and plants often established. In ASS, this practice does not look promising, either under aerobic or anaerobic soil conditions and would lead to severe acidification. Progress has been made in the use of organic matter as an alternative strategy compared to the conventional use of lime addition and management of the water table. Most of the data available are from 
studies limited to the laboratory or glasshouse with organic matter prepared to suit these conditions and studies dealing with establishing how much organic matter would be needed under field conditions and frequency of the additions are limited. The time course of effects of organic matter warrants further investigation as this will set the basis for the frequency of addition and how long the changes in soil chemistry induced last. When findings of more studies become available, bioremediation of ASS looks more promising for general soil use and management, which cannot be achieved conventionally using lime or management of the water table.

\section{ACKNOWLEDGMENT}

Most of my studies reviewed came out as a result of large body of data collected working with Professor Rob J. Reid, Earth and Environmental Science, School of Biological Sciences, The University of Adelaide, Adelaide, South Australia. I learned to think critically and develop better analytical skills under Rob. All the ASS terminologies came from Professor Rob Fitzpatrick, Acid Sulfate Soils Centre, The University of Adelaide, Adelaide, South Australia.

\section{REFERENCES}

Armstrong W. 1980. Aeration in higher plants. Advances in Botanical Research 7: 225-332

Baldwin DS and Fraser M. 2009. Rehabilitation options for inland waterways impacted by sulfidic sediments - A synthesis. Journal of Environmental Management 91(2):311-319

Billings SA and Ziegler SE. 2005. Linking microbial activity and soil organic matter transformations in forest soils under elevated $\mathrm{CO}_{2}$. Global Change Biology 11(2):203-212

Bloomfield C and Coulter JK. 1973. Genesis and management of acid sulfate soils. Advances in Agronomy 25:265-239

Bush RT, Sullivan LA, Fyfe D \& Johnson S. 2004. Redistribution of monosulfidic black oozes by floodwaters in a coastal acid sulfate soil floodplain. Australian Journal of Soil Research 42(5):603-607

Canfield DE, Olesen CA \& Cox RP. 2006. Temperature and its control of isotope fractionation by sulfate-reducing bacterium. Geochimica et Cosmochimica Acta 70:548-561

Charoenchamratcheep C, Smith CJ, Satawathananont S \& Patrick WH Jr. 1987. Reduction and oxidation of acid sulfate soils of Thailand. Soil Science Society of America Journal 51(3):630-634

Connell WE and Patrick WH Jr. 1968. Sulfate reduction in soil: Effects of redox potential and pH. Science 159(3810):86-87

Cook FJ, Hicks W, Gardner EA, Carlin GD \& Froggatt DW. 2000. Export of Acidity in Drainage Water from Acid Sulphate Soils. Marine Pollution Bulletin 41(7-12): 319-326

Cook FJ, Gardner EA \& Rassam D. 2001. Prediction and management of acidity production and export from acid sulphate soils used for sugarcane production, Department of Natural Resources and Mines, Queensland, Australia 
Management of acid sulfate soils under aerobic and anaerobic soil conditions

Coleman D and Wall D. 2007. Fauna: the engine for microbial activity and transport. In Paul E (ed) Soil microbiology, ecology, and biochemistry (pp163-194). Academic Press, Amsterdam, The Netherlands

Dear SE, Moore NG, Dobos SK, Watling KM \& Ahern CR. 2002. Soil Management Guidelines, Queensland Acid Sulfate Soil Technical Manual. Department of Natural Resources and Mines, Indooroopilly, Queensland

Dent DL. 1992. Remediation of acid sulfate soils. Advances in Soil Science 17:79122

Dent DL. 1986. Acid sulphate soils: a baseline for research and development, International Institute for Land Reclamation and Improvement/ILRI, Wageningen, Netherlands

Dent DL and Pons LJ. 1995. A world perspective on acid sulphate soils. Geoderma 67(3-4):263-276

Dubey AK and Sahu O. 2014. Phragmites australis (Marsh Plant) as wastewater treatment material. International Journal of Agricultural Research and Review 1(2):48-55

Fanning D. 2015. Phriends of Phragmites. Pedologue (Fall issue):5-8.

Fitzpatrick R, Powell B \& Marvanek S. 2008. Atlas of Australian acid sulfate soils. In Fitzpatrick RW and Paul P (eds) Inland Acid Sulfate Soil Systems Across Australia (pp75-89). CRC LEME Open File Report No. 249. CRC LEME, Perth, Australia

Fitzpatrick RW, Grealish G, Shand P, Simpson SL, Merry RH \& Raven MD. 2009. Acid Sulfate Soil Assessment in Finniss River, Currency Creek, Black Swamp, and Goolwa Channel, South Australia. Prepared for the Murray Darling Basin Authority. CSIRO Land and Water Science Report 26/09 (pp213). CSIRO, Adelaide

Fitzpatrick RW, Grealish G, Chappell A, Marvanek S \& Shand P. 2010. Spatial variability of subaqueous and terresterial Acid Sulfate Soils and their properties, for the Lower Lakes, South Australia. Report prepared for Department of Environment and Natural Resources (DENR) Murray Futures Lower Lakes \& Coorong Recovery Acid Sulfate Soils Research

Fitzpatrick RW, Raven MD, Self PG, Shand P, Mosley L, Simpson S \& Baker A. 2012. Occurrence, genesis and environmental significance of schwertmannite in re-flooded Acid Sulfate Soils in the Lower Murray Reclaimed Irrigation Area . Proceedings Combined Australian Regolith Geoscientists Association and Australian Clay Minerals Society Conference: Proceedings (pp147-152), Mildura, 7-10 February, 2012

Fortin D, Davis B \& Beveridge TJ. 1996. Role of Thiobacillus and sulfate-reducing bacteria in iron biocycling in oxic and acidic mine tailings. FEMS Microbiology Ecology 21(1):11-24

Haveman SA, Greene EA, Stilwel CP, Voodouw JK \& Voodouw G. 2004. Physiological and gene expression analysis of inhibition of Desulfovibrio vulgaris Hildenborough by nitrite. Journal of Bacteriology 186(3):7944-7950

Hopkins DW and Gregorich EG. 2005. Carbon as a substrate for soil organisms. In Bardgett RD, Usher MB \& Hopkins DW (eds) Biological Diversity and Function in Soils (pp 57-79). Cambridge University Press, Cambridge, UK

Howarth W. 2007. Carbon cycling and formation of organic matter. In Paul EA (ed) Soil Microbiology, Ecology, and Biochemistry (3rd edn) (pp303-340). Academic Press, Amsterdam, The Netherlands 
Jayalath J, Mosely LM \& Fitzpatrick RW. 2016. Addition of organic matter influences $\mathrm{pH}$ changes in reduced and oxidised acid sulfate soils. Geoderma 262:125-132

Joukainen S and Yli-Halla M. 2003. Environmental impacts and acid loads from deep sulfidic layers of two well-drained acid sulfate soils in western Finland. Agriculture, Ecosystems and Environment 95(1):297-309

Kaster K, Grigoriyan A, Jennneman G \& Voodoux G. 2007. Effect of nitrate and nitrite on sulfide production by two thermophilic, sulfate-reducing enrichments from an oil field in the North Sea. Applied Microbiology and Biotechnology 75(1):195-203

Koschorreck M. 2008. Microbial sulphate reduction at a low pH. FEMS Microbiology Ecology 64(3):329-342

Lin C, O'Brien K, Lancaster G, Sullivan LA \& McConchie D. 2000. An improved analytical procedure for determination of total actual acidity (TAA) in acid sulfate soils. The Science of the Total Environment 262(1-2):57-61

Ljung K, Maley F \& Cook A. 2010. Canal estate development in an acid sulfate soilImplications for human metal exposure. Landscape and Urban Planning 97(2):123-131

Ljung K, Maley F, Cook A \& Weinstein P. 2009. Acid sulphate soils and human healthA millenium ecosystem assessment. Environment International 35(8):12341242

Marks M, Lapin B \& Randall J. 1994. Phragmites australis (P. communis): threats, management and monitoring. Natural Areas Journal 14(4):285-294

Melville MD and White I. 2012. Acid sulfate soils: Management. Encyclopedia of Environmental Management. CRC Press, Boca Raton

Michael PS, Reid R \& Fitzpatrick RW. 2012. Amelioration of slowly permeable hypersaline peaty-clayey sulfuric and sulfidic materials in acid sulfate soils by mixing with friable sandy loam soil. In Burkitt LL and Sparrow LA (eds) Proceedings of the 5th Joint Australian and New Zealand Soil Science Conference: Soil solutions for diverse landscapes (pp 146-149). Tasmania, Australia

Michael PS. 2013. Ecological impacts and management of acid sulphate soil: A review. Asian Journal of Water, Environment and Pollution 10(4):13-24

Michael PS. 2015b. Effects of organic amendments and plants on the chemistry of acid sulfate soils under aerobic and anaerobic conditions (PhD dissertation). University of Adelaide, Adelaide, South Australia

Michael PS, Fitzpatrick RW \& Reid R. 2015. The role of organic matter in ameliorating acid sulfate soils with sulfuric horizons. Geoderma 225-256:4249

Michael PS, Fitzpatrick R \& Reid R. 2016. The importance of soil carbon and nitrogen in amelioration of acid sulphate soils. Soil Use and Management 32(1):97-105

Michael PS. 2017. The time course of effects of simple carbon and organic matter on $\mathrm{pH}$ and redox potential of acid sulfate soils. International Journal of Agricultural and Environmental Research 3(4):350-359

Michael PS, Fitzpatrick WR \& Reid JR. 2017. Effects of live wetland plant macrophytes on acidification, redox potential and sulfate content in acid sulphate soils. Soil Use and Management 33(3):471-481

Michael PS and Reid RJ. 2018. Impact of common reed and complex organic matter on the chemistry of acid sulfate soils. Journal of Soil Science and Plant Nutrition 18(2):542-555 
Management of acid sulfate soils under aerobic and anaerobic soil conditions

Michael PS. 2018a. Comparative assessment of the effects of soil carbon and nitrogen amendment on surface and subsurface soil $\mathrm{pH}$, Eh and sulfate content of acid sulfate soils. Eurasian Soil Science 51(10):1181-1190

Michael PS. 2018b. The role of surface soil carbon and nitrogen in regulating surface soil pH and redox potential of sulfidic soil of acid sulfate soils. Pertanika Journal of Tropical Agricultural Science 41(4):1627-1642

Michael PS. 2018c. Effects of live plants and dead plant matter on the stability of pH, redox potential and sulfate content of sulfuric soil neutralized by addition of alkaline sandy loam. Malaysian Journal of Soil Science 22:1-18

Nordmyr L, Astrom M \& Peltola P. 2008. Metal pollution of estuarine sediments caused by leaching of acid sulphate soils. Estuarine Coastal and Shelf Science 76(1):141-152

Pons LJ. 1973. Outline of the genesis, characteristics, classifications and improvement of acid sulphate soils. In Dost $\mathrm{H}$ (ed) Proceedings of the International Symposium on Acid Sulphate Soils. Introductory Papers and Bibliography (pp3-27). International Institute for Land Reclaimation and Improvement (ILRI), Wageningen, The Netherlands

Powell B and Ahern CR. 1999. QASSMAC Acid Sulfate Soil Management Strategy for Queensland. Queensland Department of Natural Resources, Indooroopilly, Queensland

Powell B and Waite I. 2000. The Australian institutional response to 'bad news' natural resource issues-the acid sulfate soil example. In Adams JA and Metherell AK (eds) Soil 2000: New Horizions for a New Century (pp 233-234). Australia and New Zealand Second Joint Conference. New Zealand Society of Soil Science, Lincoln University, New Zealand

Rigby PA, Dobos SK, Cook FJ \& Goonetilleke A. 2006. Role of organic matter in framboid pyrite oxidation. The Science of the Total Environment 367(2-3):847854

Reid RJ and Butcher CS. 2011. Positive and negative impacts of plants on acid production in exposed acid sulphate soils. Plant and Soil 349:183-190

Roos M and Astron M. 2005. Hydrochemistry of rivers in an acid sulphate soil hotspot area in western Finland. Agricultural and Food Science 14(1):24-33

Rynk R, van de Kamp M, Willson GB, Singley ME, Richard TL, Kolega JJ, Gouin FR, Laliberty L Jr., Kay D, Murphy DW, Hoitink HAJ \& Brinton WF. 1992. On-farm Composting Handbook (pp186). Natural Resource Agriculture and Engineering Service, Ithaca, New York

Shamshuddin J, Muhrizal S, Fauziah I \& Husni MHA. 2004. Effects of adding organic materials to an acid sulfate soil on the growth of cocoa (Theobroma cacao L.) seedlings. The Science of the Total Environment 323(1-3):33-45

Simpson HJ and Pedini M. 1985. Brackishwater aquaculture in the tropics: the problem of acid sulfate soils. FAO Fisheries Circular 791:32

Sullivan LA, Fitzpatrick RW, Bush RT, Burton ED, Shand P \& Ward NJ. 2010. The classification of acid sulfate soil materials: further modifications. Southern Cross GeoScience Technical Report No. 310. Southern Cross University, Lismore, NSW, Australia

Thomas BP. 2010. Coastal acid sulfate soil processes in Barker Inlet, South Australia (PhD dissertation). The University of Adelaide

Tinh TK, Huong HTT \& Nilsson SI. 2001. Rice-soil interactions in Vietnamese acid sulphate soils: impacts of submergence depth on soil solution chemistry and 
yields. Soil Use and Management 17(2):67-76

Tornberg T, Bendix M \& Brix H. 1994. Internal gas transport in Typha latifolia L. and Typha angustifolia L. 2. Convective throughflow pathways and ecological significance. Aquatic Botany 49(2-3):91-105

Vegas-Vilarrubia T, Baritto F \& Melean G. 2008. Critical examination of some common field tests to assess the acid-sulfate condition in soils. Soil Use and Management 24(1):60-68

Ward NJ, Sullivan LA \& Bush RT. 2004a. The response of partially oxidised acid sulfate soil materials to anoxia. Australian Journal of Soil Research 42(5):515525

Ward NJ, Sullivan LA \& Bush RT. 2004b. Soil pH, oxygen availability, and the rate of sulfide oxidation in acid sulfate soil materials: implications for environmental hazard assessment. Australian Journal of Soil Research 42(6):509-514

Wardle DA. 2002. Communities and ecosystems - linking the aboveground and belowground components. Princeton: Princeton University Press

Widdel F. 1988. Microbiology and ecology of sulfate-and sulfur reducing bacteria. In Zehnder A (ed) Biology of Anaerobic Microorganisms (pp469-585). John Wiley \& Sons, Inc., New York

Yan F, Schubert S \& Mengel K. 1996. Soil pH changes during legume growth and application of plant materials. Biology and Fertility of Soils 23(3):236-242

Yuan C, Fitzpatrick R, Mosely LM \& Marschner P. 2015a. Sulfate reduction in sulfuric material after re-flooding:Effectiveness of organic matter addition and $\mathrm{pH}$ increase depends on soil properties. Journal of Harzardous Materials 298: 138-145

Yuan C, Morsely LM, Fitzpatrick R \& Marschner P. 2015b. Amount of organic matter required to induce sulfate reduction in sulfuric material after re-flooding is affected by soil nitrate concentration. Journal of Environmental Management $151: 437-442$ 